\title{
Effects of plane of nutrition and 2,4-thiazolidinedione on insulin responses and adipose tissue gene expression in dairy cattle during late gestation
}

\author{
K. M. Schoenberg and T. R. Overton ${ }^{1}$ \\ Department of Animal Science, Cornell University, Ithaca, NY 14853
}

\section{ABSTRACT}

Specific mechanisms by which dry period dietary energy affects transition cow metabolism have been intensively investigated but those of thiazolidinedione (TZD) administration have not. We hypothesized that effects of both are mediated via changes in insulin, glucose, or fatty acid metabolism. The objective of this experiment was to determine the effects of the insulin-sensitizing agent TZD and dietary energy level on glucose and fatty acid metabolism during late gestation in dairy cows. Multiparous Holstein cows $(\mathrm{n}=32)$ approximately 50 $\mathrm{d}$ before expected calving date were dried-off and assigned to 1 of 2 dietary energy levels for 3 wk (high: $1.52 \mathrm{Mcal} / \mathrm{kg}$ of $\mathrm{NE}_{\mathrm{L}}$, or low: $1.34 \mathrm{Mcal} / \mathrm{kg}$ of $\mathrm{NE}_{\mathrm{L}}$ ) and treated daily during the final $14 \mathrm{~d}$ with $4.0 \mathrm{mg}$ of TZD/kg of body weight (BW) or saline in a completely randomized design. Cows fed the low energy diet had lower dry matter intake (12.8 vs. $16.1 \mathrm{~kg} / \mathrm{d})$ and higher plasma nonesterified fatty acid (NEFA) concentrations (103.3 vs. $82.4 \mu \mathrm{Eq} / \mathrm{L}$ ) compared with cows fed the high energy diet. Cows administered TZD had higher plasma glucose concentrations (62.5 vs. $59.6 \mathrm{mg} / \mathrm{dL}$ ) than saline controls and cows fed the high energy diet had higher plasma insulin concentrations (35.1 vs. 25.3 $\mu \mathrm{U} / \mathrm{mL}$ ) compared with those fed the low energy diet. After 2 wk of TZD treatment, all cows were subjected to an intravenous glucose tolerance test (GTT; $0.25 \mathrm{~g}$ of dextrose $/ \mathrm{kg}$ of $\mathrm{BW}$ ) followed 110 min later by an insulin challenge (IC; $1.0 \mu \mathrm{g}$ of insulin $/ \mathrm{kg}$ of BW). Differences in plasma glucose response to GTT were minimal based on diet; however, cows fed the low energy diet had more negative NEFA areas under the curve (AUC; $-4,838$ vs. $-2,137 \mu \mathrm{Eq} / \mathrm{L} \times \min$ over $90 \mathrm{~min}$ ) and greater rates of NEFA decrease (1.35 vs. $0.63 \%$ / min) during GTT, suggesting differential responses of tissue glucose and fatty acid metabolism in response to dietary energy level. During IC, the TZD-treated cows tended to have more negative glucose AUC ( -45.0 vs. $-12.1 \mathrm{mg} / \mathrm{dL} \times \min$ over $15 \mathrm{~min})$ than controls, sug-

Received May 13, 2011.

Accepted September 2, 2011.

${ }^{1}$ Corresponding author: tro2@cornell.edu gesting that TZD-treated cows had greater responses to insulin. Limited interactions were observed between dietary and TZD treatments in all response variables measured. Adipose tissue biopsies performed on the final day of treatment suggested higher expression of peroxisome proliferator-activated receptor- $\gamma$ ( 0.71 vs. 0.50 relative expression) and lipoprotein lipase (0.71 vs. 0.40 relative expression) in cows fed the high energy diet as measured by quantitative real-time PCR. These results indicate that energy level and insulin-sensitizing agents affect glucose and lipid metabolism during the dry period.

Key words: thiazolidinedione, insulin, adipose tissue

\section{INTRODUCTION}

The transition period requires complex coordination of tissues to support the onset of lactation (Bauman and Currie, 1980). Although the transition period was defined by Grummer (1995) as the 3 wk before and following calving, much research has focused on the role of nutrition during the far-off as well as the closeup dry periods. Maximizing prepartum DM or energy intake had previously been recommended (Curtis et al., 1985; Grummer, 1995); however, many research groups have reported potentially negative consequences of overfeeding cows during the dry period (Grummer, 1995; Holtenius et al., 1996, 2003; Dann et al., 1999, 2005, 2006; Agenäs et al., 2003). Historical evidence for the negative consequences of overfeeding during the dry period existed even earlier (Gardner, 1969; Coppock et al., 1972) as it was often referred to as "fat cow syndrome" (Morrow, 1976). Many of the more recent experiments reported sharper decreases in DMI and more dramatic increases in plasma NEFA concentrations pre- and postcalving for cows that were overfed during the dry period. The consequences of excessive postpartum mobilization of adipose tissue are increased incidences of metabolic disorders such as ketosis and fatty liver due to prolonged negative energy balance (Fronk et al., 1980; Vasquez-Añon et al., 1994; reviewed by Grummer, 1993; Vernon, 2005).

Feeding a controlled energy diet throughout the dry period has been shown to limit body condition losses 
postcalving, especially if gain in body condition is limited (Garnsworthy and Topps, 1982; Murondoti et al., 2004; Richards et al., 2010). Furthermore, recent data suggest that changes in energy metabolism may occur with overfeeding without observable changes in BCS. In a group of nonpregnant dry cows that were fed either a low $\left(\mathrm{NE}_{\mathrm{L}}=1.37 \mathrm{Mcal} / \mathrm{kg}\right)$ or moderate $\left(\mathrm{NE}_{\mathrm{L}}=1.61 \mathrm{Mcal} / \mathrm{kg}\right)$ energy level, the cows that were fed the moderate energy level deposited $>70 \%$ more internal fat despite no significant differences in assigned BCS (Nikkhah et al., 2008). Therefore, changes in BCS alone may not be sufficient to determine the effects of overfeeding on transition cow metabolism. A better understanding of coordinated changes in whole-body metabolism during situations of overfeeding is necessary.

Insulin, and potentially changes in tissue responses to insulin, may be a key factor in these alterations in energy metabolism in overfed cows. Cows fed at $178 \%$ of calculated energy requirements during the entire dry period had greater insulin responses to glucose challenge, indicating insulin resistance (Holtenius et al., 2003). Dann et al. (2006) reported that cows fed at $150 \%$ of NRC-predicted energy requirements in the far-off dry period had higher NEFA and BHBA concentrations and lost more BW postcalving despite having higher insulin levels during the dry period. The potential role for insulin resistance in overfed cows and the mediation thereof is not known.

The use of an insulin-sensitizing agent, 2,4-thiazolidinedione (TZD), in transition dairy cattle resulted in increased DMI and decreased plasma NEFA concentrations during the transition period (Smith et al., 2007, 2009). This peroxisome proliferator-activated receptor- $\gamma$ (PPAR $\gamma)$ ligand has insulin sensitizingeffects targeted to adipose tissue (Sundvold et al., 1997; Hammarstedt et al., 2005). The first use of TZD in ruminants reversed tumor necrosis factor- $\alpha$ (TNF $\mathbf{\alpha}$ )induced insulin resistance, further supporting its potential application during the transition period (Kushibiki et al., 2001).

Much of the research conducted on plane of nutrition in dry cows has focused on responses in BCS loss and corresponding metabolites; therefore, the need exists for further study of adipose tissue metabolism. Overfeeding during the dry period resulted in increased esterification rates in adipose tissue prepartum (concurrent with higher circulating insulin concentrations; Rukkwamsuk et al., 1999) and greater lipolytic rates (and thus higher NEFA concentrations) postpartum (Rukkwamsuk et al., 1999). These changes in regulation partially explain the greater postpartum loss of body condition observed in cows overfed during the dry period. Given these observations, the potential mechanisms by which con- trolled plane of nutrition and insulin-sensitizing agents can positively affect the metabolic health of transition dairy cows need clarification.

Therefore, the objectives of this experiment were to determine the effects of dietary energy level and administration of an insulin-sensitizing agent (TZD) on glucose and fatty acid metabolism during the dry period. Specifically, what effect would excessive energy intake have on plasma concentrations of glucose, insulin, and NEFA, and what interactions would exist between dietary energy level and TZD administration? To determine these effects, responses to glucose and insulin challenges and responses in gene expression in adipose tissue were measured. The hypothesis was that plane of nutrition would affect energy metabolism related to insulin resistance, with potential interactions of TZD and dietary treatment.

\section{MATERIALS AND METHODS}

\section{Animals, Treatments, and Sampling}

All procedures involving animals were approved before the onset of the experiment by the Cornell University Institutional Animal Care and Use Committee. The animal phase of this experiment took place from November 2009 through February 2010. Holstein cows $(\mathrm{n}=32)$ entering second or greater lactation were selected from the Cornell Teaching and Research Center dairy herd, dried off at approximately $50 \mathrm{~d}$ before expected calving date, and moved to individual tie stalls to begin the experiment within 1 wk. Based on actual calving dates, cows began the experiment an average of $48( \pm 8) \mathrm{d}$ before calving. Cows were assigned randomly to 1 of 2 dietary treatments: those fed a high plane of nutrition (HN) or those fed a low plane of nutrition $(\mathbf{L N})$, based on dietary energy level and the resulting DMI. Ingredient and chemical composition of the experimental diets are detailed in Table 1. Samples of concentrate mixtures and TMR were obtained weekly throughout the experiment, and DM content was determined by drying at $55^{\circ} \mathrm{C}$ until a static weight was observed. Dry matter contents of the TMR were used in calculating DMI for the corresponding week. The weekly TMR samples were composited into 4-wk composite samples and submitted (3 each for both $\mathrm{HN}$ and LN diets) to a commercial laboratory for wet chemistry analysis (Dairy One Cooperative Inc., Ithaca, NY). Samples were analyzed for DM (method 930.15; AOAC, 2000), CP (method 990.03; AOAC, 2000), ADF and NDF (Van Soest et al., 1991), macro- and microminerals (Sirois et al., 1994), neutral detergent insoluble CP and acid detergent insoluble CP (Licitra et al., 1996), ether extract (method 2003.05; AOAC, 
Table 1. Experimental diet ingredients and chemical composition for animals on a high and low plane of nutrition

\begin{tabular}{|c|c|c|}
\hline Item & High & Low \\
\hline \multicolumn{3}{|l|}{ Ingredient (\%, DM basis) } \\
\hline Corn silage, processed & 62.7 & 32.3 \\
\hline Soybean hulls & 9.5 & 10.8 \\
\hline Distillers grains (with solubles) & 9.1 & 3.6 \\
\hline Wheat straw & 7.0 & 33.4 \\
\hline AminoPlus $^{1}$ & 6.2 & 7.0 \\
\hline Soybean meal & 3.12 & 3.53 \\
\hline Calcium carbonate & 1.23 & 1.23 \\
\hline Molasses & 0.68 & 0.86 \\
\hline Salt & 0.27 & 0.31 \\
\hline Magnesium oxide & 0.05 & 0.06 \\
\hline Selenium $0.06 \%$ & 0.03 & 0.03 \\
\hline Vitamin A, D, E premix ${ }^{2}$ & 0.03 & 0.03 \\
\hline Trace mineral premix ${ }^{3}$ & 0.03 & 0.03 \\
\hline Zinc sulfate & 0.0003 & 0.0003 \\
\hline Vitamin E premix ${ }^{4}$ & 0.0003 & 0.0003 \\
\hline \multicolumn{3}{|l|}{ Chemical composition $( \pm \mathrm{SD})^{5}$} \\
\hline $\mathrm{NE}_{\mathrm{L}}^{6}(\mathrm{Mcal} / \mathrm{kg})$ & $1.52(0.02)$ & $1.34(0.05)$ \\
\hline $\mathrm{CP}(\%)$ & $13.5(0.51)$ & $14.0(0.40)$ \\
\hline Soluble protein (\% of CP) & $33.7(0.58)$ & $30.3(1.5)$ \\
\hline Acid detergent insoluble CP (\%) & $0.70(0.06)$ & $0.80(0.06)$ \\
\hline Neutral detergent insoluble CP (\%) & $2.4(0.2)$ & $2.9(0.4)$ \\
\hline $\operatorname{ADF}(\%)$ & $25.6(1.6)$ & $35.0(1.9)$ \\
\hline NDF $(\%)$ & $41.4(0.5)$ & $52.3(0.8)$ \\
\hline Starch $(\%)$ & $25.9(0.7)$ & $15.2(0.7)$ \\
\hline $\operatorname{NFC}^{7}(\%)$ & $39.3(1.0)$ & $28.1(0.7)$ \\
\hline Ether extract (\%) & $2.1(0.3)$ & $2.2(0.3)$ \\
\hline $\operatorname{Ash}(\%)$ & $6.1(0.2)$ & $6.4(0.2)$ \\
\hline $\mathrm{Ca}(\%)$ & $0.60(0.08)$ & $0.70(0.04)$ \\
\hline $\mathrm{P}(\%)$ & $0.30(0.01)$ & $0.43(0.01)$ \\
\hline K $(\%)$ & $1.20(0.08)$ & $1.10(0.03)$ \\
\hline $\mathrm{Mg}(\%)$ & $0.20(0.01)$ & $0.20(0.00)$ \\
\hline $\mathrm{Na}(\%)$ & $0.20(0.03)$ & $0.20(0.03)$ \\
\hline $\mathrm{Cl}(\%)$ & $0.30(0.01)$ & $0.30(0.02)$ \\
\hline S (\%) & $0.20(0.01)$ & $0.20(0.01)$ \\
\hline $\mathrm{DCAD}^{8}(\mathrm{mEq} / 100 \mathrm{~g}$ of $\mathrm{DM})$ & $17.7(0.6)$ & $15.0(0.0)$ \\
\hline
\end{tabular}

${ }^{1}$ Rumen undegradable protein supplement; AGP Inc. (Omaha, NE).

${ }^{2}$ Contained $30,464 \mathrm{IU} / \mathrm{kg}$ of vitamin A, 5,862 IU $/ \mathrm{kg}$ of vitamin D, and 93,784 IU $/ \mathrm{kg}$ of vitamin E.

${ }^{3}$ Contained $18.8 \% \mathrm{~S}, 153,916 \mathrm{mg} / \mathrm{kg}$ of $\mathrm{Zn}, 20,317 \mathrm{mg} / \mathrm{kg}$ of $\mathrm{Cu}, 136,486 \mathrm{mg} / \mathrm{kg}$ of $\mathrm{Mn}, 3,393 \mathrm{mg} / \mathrm{kg}$ of Co, and $3,040 \mathrm{mg} / \mathrm{kg}$ of I.

${ }^{4}$ Contained 499,400 IU/kg of vitamin E.

${ }^{5}$ Based upon 3 composite samples of each diet.

${ }^{6}$ Predicted using Cornell Net Carbohydrate and Protein System (CNCPS, v. 6.1, Cornell University, Ithaca, NY).

${ }^{7}$ Calculated as $100-[(\mathrm{NDF}-\mathrm{NDFCP})+\mathrm{CP}+$ ash + ether extract $]$ (NRC, 2001).

${ }^{8}$ Calculated as mEq $[(\mathrm{Na}+\mathrm{K})-(\mathrm{Cl}+\mathrm{S})] / 100 \mathrm{~g}$ of DM $(\mathrm{NRC}, 2001)$.

2000), ash (method 942.05; AOAC, 2000), and starch (Application note 319, TSI Inc., Yellow Springs, OH). Both diets were fed for ad libitum intake once per day at approximately $1000 \mathrm{~h}$ for a total of $3 \mathrm{wk}$.

On $\mathrm{d} 7$ of the experiment, cows were fitted with indwelling jugular catheters (Micro-Renathane Implantation tubing, $2.03 \mathrm{~mm}$ o.d. $\times 1.02 \mathrm{~mm}$ i.d.; Braintree Scientific Inc., Braintree, MA) by percutaneous venipuncture. Prior to insertion, the area on the neck was clipped to remove the hair, cleaned aseptically using Betadine scrub (Betadine Surgical Scrub, $7.5 \%$ povidone-iodine, Purdue Frederick, Stamford, CT) and 70\% ethanol in water. The jugular vein was punctured using a 12-gauge Medicut (12-g, 5-cm Medicut intravenous cannula, Tyco Healthcare, Gosport, UK) needle and catheter insertion sleeve. Once the needle was removed, approximately $30 \mathrm{~cm}$ of sterile catheter was inserted through the sleeve into the jugular vein. The catheter was checked for proper function and the sleeve was removed. The catheter was flushed with sterile saline, left filled with sterile saline containing $200 \mathrm{IU} / \mathrm{mL}$ heparin, and secured to the skin of the neck using a butterfly and tag cement, placed within bandages. Then, the entire neck was wrapped with an elastic bandage (Optiplaste 
4", BSN Medical Ltd., Brierfield, UK) and wrap (Coflex 4", Andover Healthcare, Salisbury, MA) to prevent the cow from dislodging the catheter. Patency of the catheters was maintained with regular flushing with heparinized saline $(10 \mathrm{IU} / \mathrm{mL}$ for frequent sampling; 100-500 IU/mL otherwise). Heparinized saline with an antibiotic was used for overnight storage of catheters to prevent bacterial growth (Naxcel, $4 \mathrm{mg} / \mathrm{mL}$ of saline, Pfizer Inc., New York, NY). We observed no infections or complications in cows with catheters installed for 2 wk.

Body weights were determined for all cows before beginning the feeding period, and again once per week until the end of the trial. Two individuals recorded BCS (Wildman et al., 1982) for all cows before the start of the experiment, and weekly until the conclusion of the trial. The average BCS for both individuals was recorded as the BCS for each cow at a given time period. Daily blood samples $(10 \mathrm{~mL})$ were collected at approximately $1200 \mathrm{~h}$ each day via coccygeal venipuncture before catheter insertion and via jugular catheter beginning on d 8. Additionally, a blood sample was drawn before the start of the experiment to serve as a covariate for each animal.

Beginning on $\mathrm{d} 8$ of the experiment, cows were infused with a TZD solution at a dose used previously in steers and dairy cattle $(4 \mathrm{mg} / \mathrm{kg}$ of BW; Kushibiki et al., 2001; Smith et al., 2007, 2009). The BW used to calculate dose was an average of the $2 \mathrm{BW}$ measurements collected on $\mathrm{d} 1$ and 7 of the experimental period. The TZD dose for each cow was solubilized into $60 \mathrm{~mL}$ of saline solution as follows. All glassware and weighing tools were sterilized via autoclave before preparation of the solution. The crystalline TZD (2,4-thiazolidinedione, technical grade, 90\%, Sigma-Aldrich Corp., St. Louis, MO) was weighed into sterilized glass bottles for each cow and $60 \mathrm{~mL}$ of sterile saline $(0.9 \% \mathrm{wt}: \mathrm{vol})$ was added to the bottle. The bottles were then capped with rubber Wheaton stoppers and aluminum seals (AluminumSeal 20mm FlipCap, Wheaton Science Products, Millville, NJ), placed into a hot water bath $\left(37^{\circ} \mathrm{C}\right)$ for 20 min, and vortexed until TZD remained in solution. Storage of bottles overnight for the next day was at room temperature and devoid of light. On the morning of dose administration, the aluminum seal on each bottle was opened and the TZD solution was removed through the rubber stopper via a sterile needle and 60$\mathrm{mL}$ syringe. If syringes were exposed to extreme cold for a long period, TZD had a tendency to come out of solution, at which time a warm water bath and shaking was sufficient to resolubilize the TZD. Each cow received $60 \mathrm{~mL}$ of TZD solution (TZD treatment) or 60 $\mathrm{mL}$ of saline (control) per day during the final $2 \mathrm{wk}$ of the experiment. Doses were administered to each cow at approximately $1300 \mathrm{~h}$ each day via jugular catheter.

\section{Glucose Tolerance Tests and Insulin Challenges}

At the end of the experiment (d 22), all cows were subjected to an intravenous glucose tolerance test (GTT) similar to those conducted previously (Pires et al., 2007). Feed remaining from the previous day was removed at approximately $0700 \mathrm{~h}$. Briefly, $0.25 \mathrm{~g}$ of glucose (dextrose, $50 \% \mathrm{wt} / \mathrm{vol}$ ) per $\mathrm{kg}$ of $\mathrm{BW}$ was administered in $7 \mathrm{~min}$ from multiple $60-\mathrm{mL}$ syringes (total infusion volume averaged $358 \mathrm{~mL}$ ) approximately $2 \mathrm{~h}$ after feed removal. Blood samples $(10 \mathrm{~mL})$ were collected $-15,-5,0,5,10,15,20,25,30,45,60$, and $90 \mathrm{~min}$ relative to the glucose infusion into the catheter. The -15 and -5 min samples were timed relative to the beginning of the glucose infusion. The sample at time zero was collected immediately following the conclusion of the glucose infusion and a $20-\mathrm{mL}$ saline flush. The rest of the samples were timed and collected relative to the completion of the infusion.

At 110 min following glucose infusion, an insulin challenge (IC) was administered to each cow. Although IC have historically not been combined with a GTT, the timing of the IC was deliberate to investigate more thoroughly potential changes in NEFA response to insulin. The IC was conducted during a period when plasma glucose and insulin concentrations had returned to basal levels and plasma NEFA concentrations were increasing, as typically occurs following a GTT. Although IC have recognized potential carryover effects, plasma insulin and glucose concentrations were at levels similar to those before the GTT, and a period of dynamic changes in plasma NEFA responses was targeted. For the IC, cows received $1 \mu \mathrm{g}$ of insulin (insulin from bovine pancreas, $\geq 27$ USP units/mg, Sigma Aldrich, St. Louis, MO) per $\mathrm{kg}$ of BW at a solution concentration of $0.2 \mathrm{mg} / \mathrm{mL}$. The total injection volume averaged $2.45 \mathrm{~mL}$. The insulin dose was followed immediately by $20 \mathrm{~mL}$ of saline flush. Blood samples were then collected at 5, 10, 15, 20, 25, 30, 45, 60, 75, 90, 120, and $180 \mathrm{~min}$ following the insulin injection.

\section{Plasma Analyses}

Blood samples, regardless of collection methods, were transferred into glass test tubes containing sodium heparin (100 IU/mL of blood). Plasma was harvested following centrifugation $\left(2,800 \times g\right.$ for $15 \mathrm{~min}$ at $\left.4^{\circ} \mathrm{C}\right)$, snap-frozen in liquid $\mathrm{N}_{2}$, and stored at $-20^{\circ} \mathrm{C}$ until analyses for metabolites and insulin. Plasma concentrations of glucose were determined by an adapted 
enzymatic analysis (glucose oxidase) using commercial products (PGO Enzyme Preparation and $o$-dianisidine dihydrochloride, Sigma-Aldrich). Intra- and interassay CV were 4.9 and $8.0 \%$, respectively. Plasma concentrations of NEFA were also analyzed by enzymatic analysis [HR Series NEFA HR (2), Wako Pure Chemical Industries, Osaka, Japan]. Intra- and interassay CV were 4.1 and 9.7\%, respectively. All spectrophotometric measurements were conducted using a Versamax tunable microplate reader (Molecular Devices, Sunnyvale, CA). Plasma concentrations of insulin were determined by double-antibody RIA (Porcine Insulin RIA cat. no. PI-12K, Linco Research, Millipore, St. Charles, MO), with a reported specificity to bovine insulin of $90 \%$. Intra- and interassay CV for the insulin assay were 1.7 and $7.5 \%$, respectively.

\section{Adipose Tissue Biopsies}

On d 23 of the experiment, adipose biopsies were collected from all cows. The procedure used was similar to that described by Houseknecht and Bauman (1997). The area below the spinal processes between the hips and the pins of the cow was palpated to locate an area with sufficient subcutaneous fat. The area was brushed and clipped to remove excess hair and prepared with betadine surgical scrub (Betadine Surgical Scrub, 7.5\% povidone-iodine, Purdue Frederick) and $70 \%$ ethanol in water. Cows were administered $20 \mathrm{mg}$ of the sedative xylazine hydrochloride (Rompun 2\%, Bayer Inc., Sarnia, Ontario, Canada). A local anesthetic (lidocaine $\mathrm{HCl}, 2 \%, 18 \mathrm{~mL}$ ) was injected subcutaneously around the biopsy site. A 4- to 8-cm incision was made and a small biopsy (0.5-1.5 g) was removed using sterile forceps and scalpel. The incision was closed with 6 to 12 surgical skin staples using a surgical staple gun (Precise Vista Skin Stapler 35W, 3M, St. Paul, MN). The wound was topically treated with a topical antiseptic (BluKote aerosol spray, H. W. Naylor Co., Morris, NY). Adipose tissue samples were rinsed with sterile saline, cleaned of connective tissue, cut into 3 aliquots, placed into plastic vials, and quenched in liquid $\mathrm{N}_{2}$. Cows were monitored for $7 \mathrm{~d}$ for signs of infection or fever. No cows experienced complications from the biopsies and the staples were removed after $7 \mathrm{~d}$.

\section{Quantitative Real-Time PCR}

Analysis of gene mRNA expression was done via quantitative real-time PCR. The RNA was isolated from 150 to $200 \mathrm{mg}$ of adipose tissue using the RNAeasy mini kit (Qiagen, Valencia, CA) and on-column DNase digestion with the RNase-free DNase set (Qiagen) after homogenization in $1.0 \mathrm{~mL}$ of Qiazol (Qiagen) reagent. The con- centration and integrity of RNA were determined using an Agilent 2100 BioAnalyzer (Agilent Technologies, Santa Clara, CA). Total RNA was reverse-transcribed using the ABI High Capacity cDNA reverse transcription kit with RNase Inhibitor (Applied Biosystems, Foster City, CA). The PCR reactions were carried out using Power SYBR Green (Applied Biosystems), $25 \mathrm{ng}$ of cDNA (or $2.5 \mathrm{ng}$ of cDNA for $18 \mathrm{~S}$ ), and $400 \mathrm{nmol} / \mathrm{L}$ gene-specific forward and reverse primers in a $25-\mu \mathrm{L}$ reaction volume using a 2-step program $\left(95^{\circ} \mathrm{C}\right.$ for 15 $\mathrm{s}$ followed by $60^{\circ} \mathrm{C}$ for $60 \mathrm{~s}$ ) on an ABI Prism 7000 sequence detection system (Applied Biosystems). Data were analyzed using a relative standard curve based on serial 2-fold dilutions of pooled cDNA prepared from adipose tissue samples. The expression of genes were analyzed using primers previously published: PPAR $\gamma$ and leptin (Harvatine et al., 2009), lipoprotein lipase (LPL), fatty acid synthase (FAS), $\beta$-2-microglobulin, 18S (Harvatine and Bauman, 2006), and TNFa (Komatsu et al., 2005). For each gene, an arbitrary expression level was obtained by normalizing the expression data to a nonvariant control (the geometric mean of $18 \mathrm{~S}$ expression and $\beta$-2-microglobulin).

\section{Calculations and Statistical Analysis}

Energy balance was calculated using NRC requirements during gestation (NRC, 2001) and $\mathrm{NE}_{\mathrm{L}}$ of feedstuffs as analyzed.

The revised quantitative insulin sensitivity check index (RQUICKI), a relative insulin sensitivity measure used in ruminants, was calculated as follows (Holtenius and Holtenius, 2007):

$$
\text { RQUICKI }=1 /\left[\log \left(\mathrm{G}_{\mathrm{b}}\right)+\log \left(\mathrm{I}_{\mathrm{b}}\right)+\log \left(\mathrm{NEFA}_{\mathrm{b}}\right)\right],
$$

where $G_{b}=$ basal glucose $(\mathrm{mg} / \mathrm{dL}), \mathrm{I}_{\mathrm{b}}=$ basal insulin $(\mu \mathrm{U} / \mathrm{mL})$, and $\mathrm{NEFA}_{\mathrm{b}}=$ basal NEFA $(\mathrm{mmol} / \mathrm{L})$, such that a lower RQUICKI suggests greater insulin resistance.

Responses to GTT and IC were measured as area under the curve (AUC), calculated using incremental change and trapezoidal rule via SAS (v. 9.2, SAS Institute Inc., Cary, NC). Additional responses such as clearance (decrease) rates, half-life, and time to reach basal concentrations were estimated using ProcNLIN of SAS (v. 9.2, SAS Institute Inc.). Clearance rate (CR; decrease rate for NEFA) was estimated using the slope of the line (for the first $30 \mathrm{~min}$ for responses in plasma glucose concentrations, the first $60 \mathrm{~min}$ for plasma NEFA concentrations) generated by estimated values from SAS. Time to reach half maximal concentration was calculated as $\{[\ln (2)] / C R\} \times 100$, and time to reach basal concentration was calculated as $\{(\ln [\mathrm{ta}]-\ln [\mathrm{tb}]) /$ 
$\mathrm{CR}\} \times 100$, where ta and tb are the concentration in plasma at times a and $\mathrm{b}$ respectively.

Statistical analysis was performed as ANOVA on measures conducted over time (plasma concentrations) using the MIXED procedure (SAS Institute Inc.) for a completely randomized design with repeated measures where appropriate. The statistical model included fixed effects of covariate, treatment, time, and the interaction of treatment and time. The random effect was cow nested within treatment. For each variable, 6 covariance structures were evaluated (first-order autoregressive, heterogeneous first-order autoregressive, compound symmetry, heterogeneous compound symmetry, first-order ante-dependence, and unstructured), and the structure with the smallest Akaike's information criterion was used for further analysis. The method of Kenward-Rogers was used for calculation of denominator degrees of freedom. Covariates were dropped from the statistical model if $P>0.15$ and the data were reanalyzed. Significance was declared as $P$-values $\leq 0.05$, trends as $0.10 \geq P \geq 0.05$.

\section{RESULTS}

\section{Feed Intake, Energy Balance, BW, and BCS}

A significant effect of diet on DMI was found during the last $2 \mathrm{wk}$ of the experiment such that cows fed the HN diet consumed $16.1( \pm 0.4) \mathrm{kg} / \mathrm{d}$ of $\mathrm{DM}$ and cows fed the LN diet consumed $12.8( \pm 0.4) \mathrm{kg} / \mathrm{d}$ of DM $(P<$ $0.0001)$. A trend was observed for a diet by day interaction $(P=0.07)$ such that cows fed the HN diet consistently ate more than cows fed the LN diet (16.1 vs. 12.8 $\mathrm{kg} / \mathrm{d}$ ) throughout the experiment, and cows fed the LN diet decreased intake slightly during wk 2 of the experiment. There were no effects of TZD administration or interactions of TZD with dietary treatment $(P>0.24)$ on DMI. The resulting energy balance (NRC, 2001) for cows on each diet was $172( \pm 3.5) \%$ calculated energy balance for cows on the HN diet and $119( \pm 3.5) \%$ for cows on the LN diet during the last 2 wk of the trial $(P$ $<0.0001)$. Consistent with the lack of a direct effect of TZD administration on DMI, no effects of TZD were found on calculated energy balance $(P=0.69)$, and no interaction of diet and TZD $(P=0.48)$ was found. Cows fed the HN diet gained $0.30( \pm 0.07)$ units of BCS throughout the study and cows fed the LN diet gained 0.14 BCS $( \pm 0.07)$ (diet; $P=0.11)$. There was no effect of TZD $(P=0.43)$ nor a TZD by diet interaction $(P=$ $0.95)$ on BCS change throughout the trial.

\section{Plasma Glucose, NEFA, and Insulin Concentrations}

Figure 1 depicts data for plasma metabolites, insulin concentrations, and calculated RQUICKI based upon daily plasma samples collected during the experiment. Statistics for plasma glucose, NEFA, and insulin concentrations were completed using results from the last 2 wk of the trial as that was the period during which cows were receiving the dietary treatments as well as TZD or saline treatment. Administration of TZD increased plasma glucose concentrations (62.5 vs. 59.6 $\mathrm{mg} / \mathrm{dL} ; P=0.03)$ compared with controls. Diet did not affect daily plasma glucose concentrations $(P=$ 0.80). Administration of TZD had no effect on plasma insulin concentrations $(P=0.47)$, but cows fed the HN diet had greater plasma concentrations of insulin (35 vs. $25 \mu \mathrm{U} / \mathrm{mL} ; P=0.03)$ than those fed the $\mathrm{LN}$ diet. Cows fed the HN diet also had lower plasma NEFA concentration (82 vs. $103 \mu \mathrm{Eq} / \mathrm{L} ; P<0.0001$ ) than those fed the LN diet. For the length of the trial, cows fed the HN diet had lower RQUICKI (0.45 vs. $0.48 ; P$ $=0.03)$, but we observed no effect of TZD $(P=0.16)$ nor an interaction between diet and TZD $(P=0.89)$.

\section{GTT and IC}

Table 2 details the changes in plasma glucose levels following glucose infusion. Although the glucose AUC was numerically greater for cows fed the LN diet versus the HN diet, these differences did not reach statistical significance $(P>0.13)$. Effects on additional measures during GTT (minimum glucose, maximum glucose, clearance rate, half-life, and time to return to basal) were not significant based on dietary treatment. Furthermore, none of the GTT measures differed in response to TZD administration.

Plasma insulin responses to GTT were almost identical based on dietary treatment, but a potentially lower reaction of insulin was observed in response to GTT in cows that were administered TZD (Table 3 ). The AUC for plasma insulin responses to glucose challenge were numerically lower for cows treated with TZD versus saline (4,381 vs. $5,711 \mu \mathrm{U} / \mathrm{mL} \times \min$ over $60 \mathrm{~min})$, but did not reach statistical significance $(P>0.15)$. Additional measures of plasma insulin during GTT were not different between cows administered TZD or saline. Basal insulin concentration was higher for cows fed the $\mathrm{HN} \operatorname{diet}(19.3$ vs. $14.3 \mu \mathrm{U} / \mathrm{mL} ; P=0.02)$, as was also reflected in daily plasma levels in Figure 1, but this was the only plasma insulin response measure during GTT that was different based on dietary treatment. In addition, no interactions of diet and TZD administration on plasma insulin responses measured during GTT were observed.

Differences in plasma NEFA responses during GTT were more dramatic in cows fed the LN diet than in those fed the HN diet, as depicted in Figure 2, although no obvious differences were seen in plasma NEFA re- 

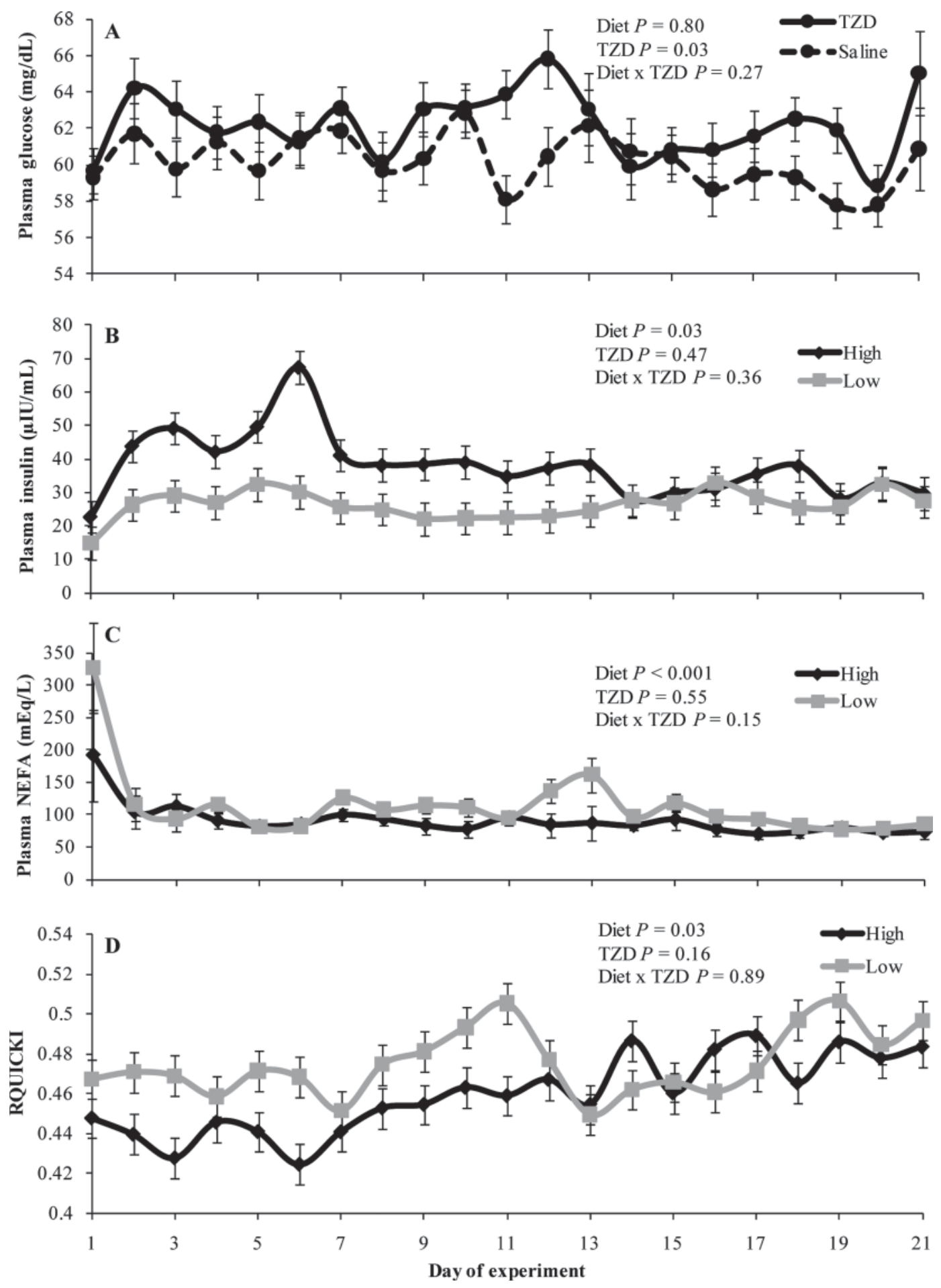

Figure 1. Daily plasma metabolites for cows fed 1 of 2 dietary treatments (high vs. low plane of nutrition) for 3 wk and treated with either thiazolidinedione (TZD) or saline intravenously for the final $2 \mathrm{wk}(\mathrm{n}=32)$. The revised quantitative insulin sensitivity check index (RQUICKI) $=1 /[\log ($ glucose $)+\log ($ insulin $)+\log ($ NEFA $)]$. Values represent least squares means, with error bars representing the SEM. The $P$-values are listed and only significant relationships are depicted graphically.

sponse to GTT with TZD administration (Table 4). Responses in plasma NEFA concentrations during GTT were different for several measures in response to dietary treatment. The decrease rate of NEFA during GTT was faster for cows fed the LN diet (Figure 2; 1.35 vs. $0.63 \% / \mathrm{min} ; P=0.01)$. Reduction in NEFA 
Table 2. Effects of diet (high or low plane of nutrition) and thiazolidinedione (TZD) treatment (versus saline control) on glucose response to i.v. glucose tolerance test (GTT)

Diet

TZD

TZD $\times$ diet interaction

\begin{tabular}{|c|c|c|c|c|c|c|c|c|c|c|c|c|c|c|}
\hline Measure $^{1}$ & High & Low & SEM & $P$-value & Saline & TZD & SEM & $P$-value & $\begin{array}{l}\text { High } \\
\text { Saline }\end{array}$ & $\begin{array}{l}\text { High } \\
\text { TZD }\end{array}$ & $\begin{array}{c}\text { Low } \\
\text { Saline }\end{array}$ & $\begin{array}{l}\text { Low } \\
\text { TZD }\end{array}$ & SEM & $P$-value \\
\hline Basal glucose $(\mathrm{mg} / \mathrm{dL})$ & 67.8 & 61.2 & 1.6 & 0.01 & 65.0 & 64.0 & 1.6 & 0.64 & 70.0 & 65.6 & 60.1 & 62.4 & 2.2 & 0.14 \\
\hline Minimum glucose (mg/dL) & 57.3 & 54.7 & 2.0 & 0.38 & 55.6 & 56.4 & 2.0 & 0.79 & 57.9 & 56.7 & 53.4 & 56.0 & 2.8 & 0.50 \\
\hline Maximum glucose $(\mathrm{mg} / \mathrm{dL})$ & 182.2 & 180.6 & 4.4 & 0.81 & 182.2 & 180.6 & 4.3 & 0.79 & 187.6 & 176.7 & 176.8 & 184.4 & 6.2 & 0.14 \\
\hline $\mathrm{CR}_{30}(\% / \mathrm{min})$ & 2.61 & 2.5 & 0.13 & 0.53 & 2.51 & 2.59 & 0.13 & 0.67 & 2.66 & 2.56 & 2.37 & 2.62 & 0.18 & 0.35 \\
\hline $\mathrm{T}_{1 / 2}(\min )$ & 27.4 & 29.6 & 1.5 & 0.32 & 29.1 & 27.9 & 1.5 & 0.57 & 27.2 & 27.6 & 31.0 & 28.2 & 2.1 & 0.45 \\
\hline $\mathrm{T}_{\text {basal }}(\min )$ & 49.3 & 55.1 & 2.8 & 0.16 & 53.8 & 50.6 & 2.8 & 0.43 & 49.9 & 48.8 & 57.8 & 52.4 & 3.9 & 0.59 \\
\hline $\mathrm{AUC}_{30}$ & 1,826 & 1,979 & 97 & 0.28 & 1,998 & 1,808 & 97 & 0.18 & 1,946 & 1,706 & 2,049 & 1,911 & 137 & 0.71 \\
\hline $\mathrm{AUC}_{60}$ & 2,029 & 2,418 & 178 & 0.13 & 2,367 & 2,080 & 178 & 0.26 & 2,164 & 1,893 & 2,571 & 2,266 & 252 & 0.95 \\
\hline $\mathrm{AUC}_{90}$ & 1,895 & 2,410 & 231 & 0.13 & 2,289 & 2,017 & 231 & 0.41 & 2,021 & 1,771 & 2,558 & 2,263 & 327 & 0.95 \\
\hline
\end{tabular}

${ }^{1}$ Basal glucose $=$ mean glucose concentration at -15 and -5 min before GTT; minimum glucose $=$ minimum glucose during GTT; maximum glucose $=$ maximum glucose during GTT; $\mathrm{CR}_{30}=$ clearance rate during the first $30 \mathrm{~min}$ of GTT; $\mathrm{T}_{1 / 2}=$ time to reach half maximal glucose concentration; $\mathrm{T}_{\text {basal }}=$ time to reach basal glucose concentration; $\mathrm{AUC} \mathrm{C}_{30}$ $=$ area under the curve during the first $30 \mathrm{~min}$ of $\mathrm{GTT}[\mathrm{mg} / \mathrm{dL} \times \min ] ; \mathrm{AUC}_{60}=$ area under the curve during the first $60 \mathrm{~min}$ of $\mathrm{GTT}[\mathrm{mg} / \mathrm{dL} \times \mathrm{min}] ; \mathrm{AUC} \mathrm{C}_{90}=\operatorname{area}$ under the curve during the first $90 \mathrm{~min}$ of GTT $[\mathrm{mg} / \mathrm{dL} \times \min ]$.

Table 3. Effects of diet (high or low plane of nutrition) and thiazolidinedione (TZD) treatment (versus saline control) on plasma insulin response to i.v. glucose tolerance test (GTT)

\begin{tabular}{|c|c|c|c|c|c|c|c|c|c|c|c|c|c|c|}
\hline \multirow[b]{2}{*}{ Measure $^{1}$} & \multicolumn{4}{|c|}{ Diet } & \multicolumn{4}{|c|}{ TZD } & \multicolumn{6}{|c|}{ TZD $\times$ diet interaction } \\
\hline & High & Low & SEM & $P$-value & Saline & TZD & SEM & $P$-value & $\begin{array}{c}\text { High } \\
\text { Saline }\end{array}$ & $\begin{array}{l}\text { High } \\
\text { TZD }\end{array}$ & $\begin{array}{c}\text { Low } \\
\text { Saline }\end{array}$ & $\begin{array}{l}\text { Low } \\
\text { TZD }\end{array}$ & SEM & $P$-value \\
\hline Basal insulin $(\mu \mathrm{IU} / \mathrm{mL})$ & 19.3 & 14.3 & 1.4 & 0.02 & 17.7 & 15.9 & 1.4 & 0.37 & 21.1 & 17.5 & 14.3 & 14.4 & 1.9 & 0.36 \\
\hline Maximum insulin $(\mu \mathrm{IU} / \mathrm{mL})$ & 214.3 & 249.3 & 29.1 & 0.40 & 241.3 & 186.8 & 29.1 & 0.65 & 241.9 & 186.8 & 240.7 & 257.9 & 41.2 & 0.39 \\
\hline $\mathrm{AUC}_{30}$ & 4,138 & 3,933 & 487 & 0.77 & 4,509 & 3,562 & 483 & 0.18 & 5,110 & 3,166 & 3,907 & 3,958 & 688 & 0.16 \\
\hline $\mathrm{AUC}_{60}$ & 5,124 & 4,967 & 643 & 0.87 & 5,711 & 4,381 & 637 & 0.15 & 6,407 & 3,842 & 5,016 & 4,919 & 901 & 0.18 \\
\hline $\mathrm{AUC}_{90}$ & 5,071 & 5,018 & 657 & 0.96 & 5,723 & 4,367 & 656 & 0.15 & 6,374 & 3,768 & 5,071 & 4,965 & 921 & 0.19 \\
\hline
\end{tabular}

${ }^{1}$ Basal insulin $=$ mean insulin concentration at -15 and -5 min before GTT: maximum insulin = maximum insulin during GTT; AUC $_{30}=$ area under the curve during the first $30 \mathrm{~min}$ of $\mathrm{GTT}[\mu \mathrm{IU} / \mathrm{mL} \times \min ] ; \mathrm{AUC}_{60}=$ area under the curve during the first $60 \mathrm{~min}$ of $\mathrm{GTT}[\mu \mathrm{IU} / \mathrm{mL} \times$ min]; AUC90 = area under the curve during the first 90 min of GTT $[\mu \mathrm{IU} / \mathrm{mL} \times \min ]$. 
also was greater in cows fed the LN diet (40.6 vs. $49.6 \%$ of basal NEFA; $P=0.05$ ). Plasma NEFA response as measured by AUC was more significant for cows fed the $\mathrm{LN} \operatorname{diet}(-4,838$ vs. $-2,137 \mu \mathrm{Eq} / \mathrm{L} \times \min$ over $90 \mathrm{~min}$; $P=0.04)$. No significant interactions were found of diet and TZD administration on plasma NEFA responses to GTT.

Figure 3 represents the changes in plasma glucose concentrations in response to IC. The only differences in plasma glucose response to IC were tendencies in AUC for plasma glucose within $15 \mathrm{~min}$ after insulin infusion $(P=0.08$; Table 5$)$. Within 15 min of insulin infusion, the AUC for plasma glucose for cows administered TZD was $-45 \mathrm{mg} / \mathrm{dL} \times \min$ over $15 \mathrm{~min}$, whereas cows receiving saline had AUC of $-12 \mathrm{mg} / \mathrm{dL} \times \min$ over $15 \mathrm{~min}$. No additional differences were found in plasma glucose responses to IC based on either dietary or TZD administration, and no significant interactions of the two were observed.

Treatment did not affect plasma insulin response to IC $(P>0.12)$. Across all treatments, basal insulin before IC was $13.6 \pm 2.1 \mu \mathrm{U} / \mathrm{mL}$, minimum insulin
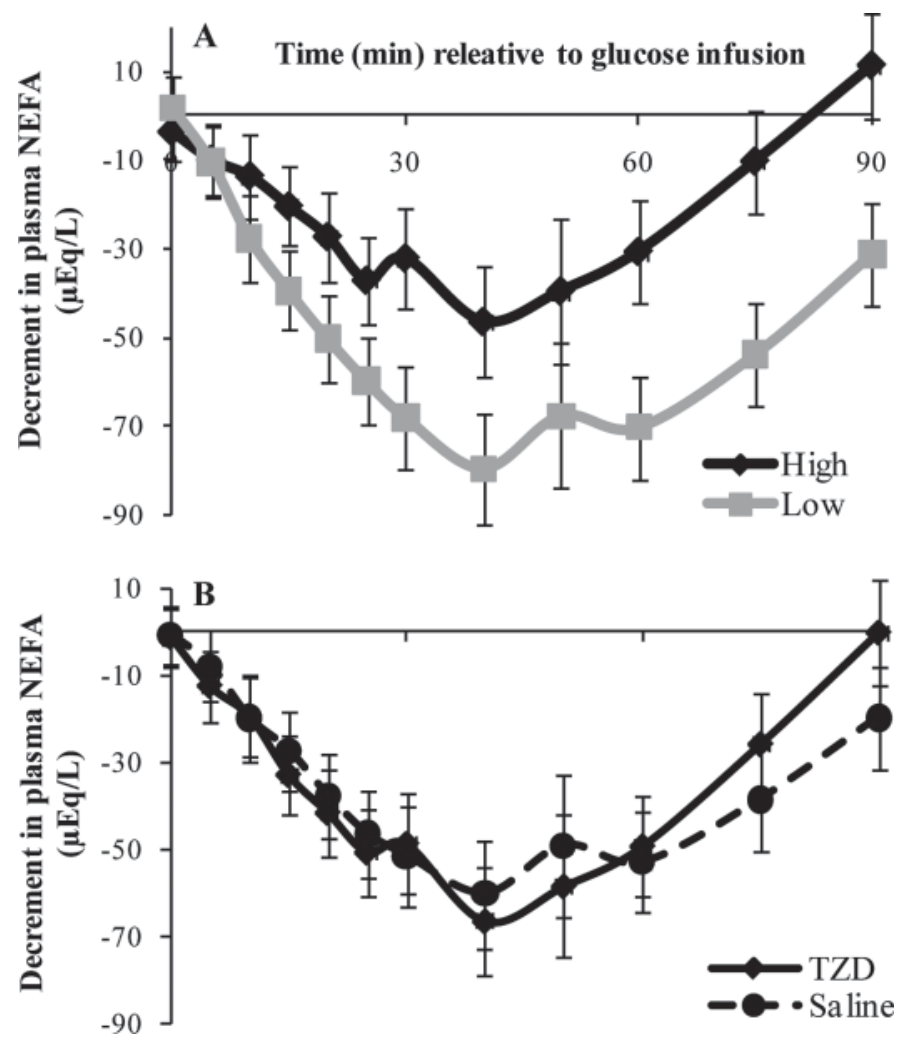

Figure 2. Plasma NEFA responses to glucose tolerance test in cows fed 1 of 2 planes of nutrition (high vs. low; A) for 3 wk and treated daily with either thiazolidinedione (TZD) or saline (TZD vs. saline; B) for the final 2 wk of the experiment. Values represent least squares means, with error bars representing the SEM; $\mathrm{n}=16$ for each treatment group depicted. Treatment effects are detailed in Table 4.
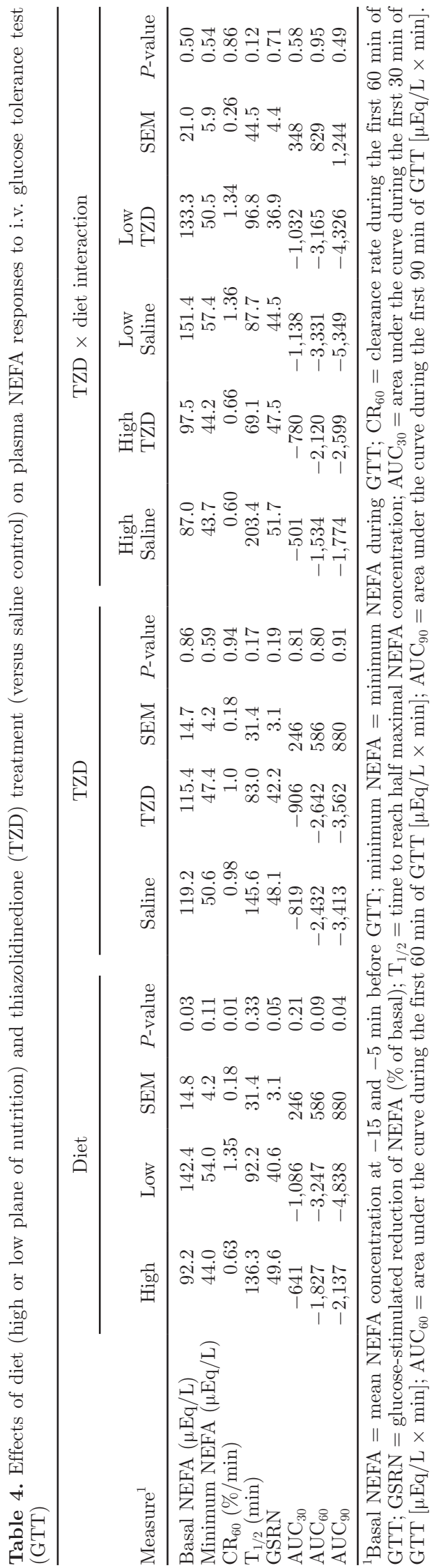

Journal of Dairy Science Vol. 94 No. 12, 2011 
during IC was $10.1 \pm 1.3 \mu \mathrm{U} / \mathrm{mL}$, and maximum insulin during IC was $149.9 \pm 47.2 \mu \mathrm{U} / \mathrm{mL}$. As detailed in Table 6, differences were found in plasma NEFA response during IC: cows administered TZD had more negative AUC during the minutes immediately following insulin infusion than cows administered the saline control ( -6.4 vs. $291.1 \mu \mathrm{Eq} / \mathrm{L} \times$ min over $15 \mathrm{~min} ; P$ $=0.04$ ). Additionally, a significant interaction of TZD and dietary treatments was observed for the same measurement $(P=0.04)$, such that cows fed the LN diet and receiving TZD had the most negative AUC $(-228$ $\mu \mathrm{Eq} / \mathrm{L} \times \min$ over $15 \mathrm{~min}$ ) and cows on the $\mathrm{LN}$ diet not receiving TZD had the most positive AUC $(979 \mu \mathrm{Eq} / \mathrm{L}$ $\times$ min over $15 \mathrm{~min}$ ), whereas cows fed the HN diet that were receiving TZD or saline control had intermediary responses in AUC $(26$ and $149 \mu \mathrm{Eq} / \mathrm{L} \times$ min over 15 min, respectively). No additional differences in plasma NEFA response to IC were observed, nor were there additional interactions of dietary and TZD treatment.

\section{Adipose Tissue Gene Expression}

A trend was observed for cows fed the HN diet to have greater expression of LPL (2.2 vs. 1.6 relative units; $P=0.10$ ) and to have significantly greater expression of PPAR $\gamma(2.4$ vs. 1.3 relative units; $P=0.02$ ). Additional differences based on dietary treatment or TZD administration or interactions of the 2 were not significant $(P>0.15)$.

\section{DISCUSSION}

The diets in this experiment were designed to achieve different planes of nutrition despite both diets being fed for ad libitum intake. The combination of lower dietary energy concentration and higher forage content of the LN diet resulted in a $53 \%$ lower calculated energy balance for cows fed the LN diet. The difference in calculated energy balance for cows fed the 2 dietary treatments was similar to that of past experimental conditions during the dry period (Dann et al., 2006). Additionally, changes in BCS for cows fed the HN diet were similar to those described in previous studies focused on changes in plane of nutrition during the dry period despite a dietary treatment period of only $3 \mathrm{wk}$ (Dann et al., 2006; Richards et al., 2010).

Because overfeeding energy to nonlactating cows has been shown to increase internal fat deposition independent of observable increases in body condition (Nikkhah et al., 2008), it could be hypothesized that cows on this experiment fed the HN diet may have deposited more visceral adipose as well as increased BCS. Unfortunately, dissection of internal adipose stores was not completed in this experiment, so results can only
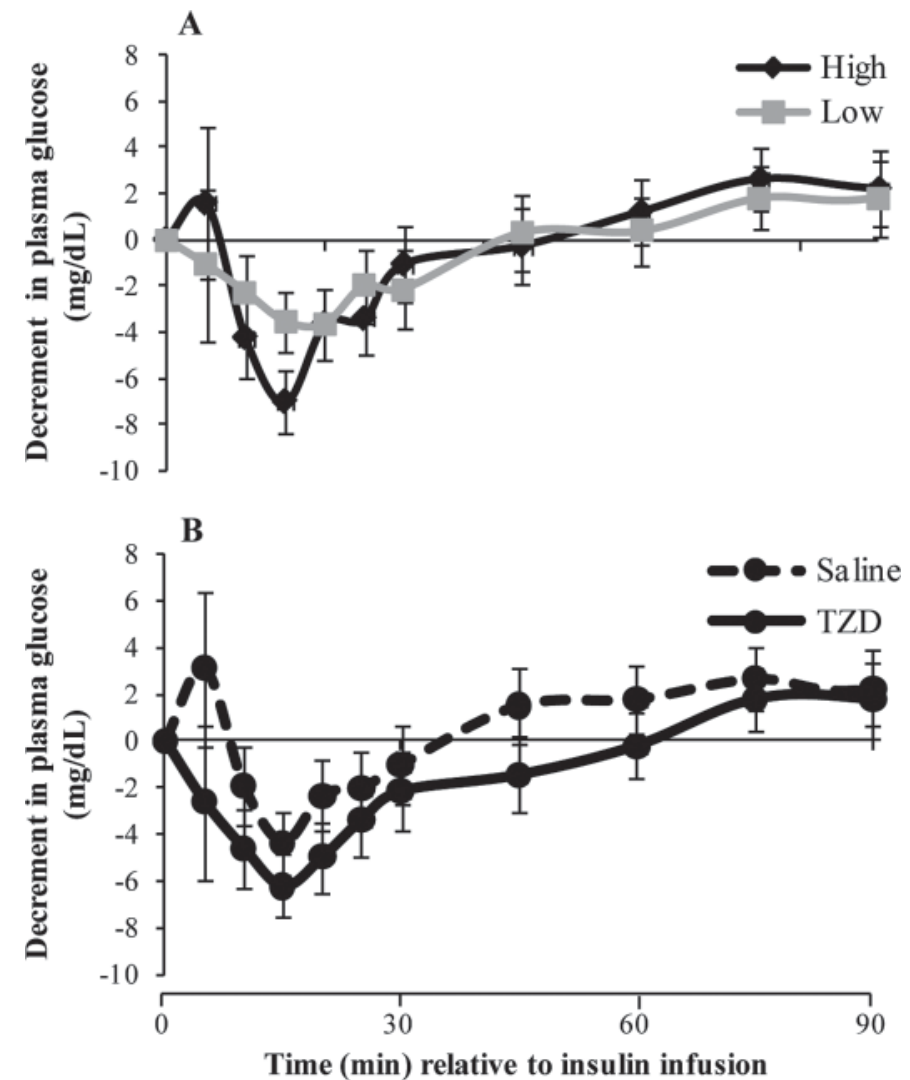

Figure 3. Plasma glucose responses to insulin challenge in cows fed 1 of 2 planes of nutrition (high vs. low; A) for 3 wk and treated daily with either thiazolidinedione (TZD) or saline (TZD vs. saline; B) for the final 2 wk of the experiment. Values represent least squares means, with error bars representing the SEM; $\mathrm{n}=16$ for each treatment group depicted. Treatment effects are detailed in Table 5.

be hypothesized. Loss of BCS postcalving was also not recorded in this experiment because cows were removed from the controlled experiment at approximately $3 \mathrm{wk}$ before calving. Given the similarities with BCS changes from other experiments, had dietary treatments continued through early lactation, more dramatic loss of BCS might have been observed for cows fed the HN diet and for cows not treated with TZD (Dann et al., 2006; Smith et al., 2007, 2009). In a previous study that administered TZD to cows prepartum (Smith et al., 2009), prepartum BCS did not differ but cows treated with TZD lost less BCS postpartum, which may parallel current results.

Administration of TZD increased plasma glucose concentrations (Figure 1A). Results of TZD treatment on plasma glucose concentrations in ruminants have been mixed such that it either tended to increase or did not increase plasma glucose concentrations during TZD administration (Smith et al., 2007, 2009). In steers that were treated with $\mathrm{TNF} \alpha$ and that had elevated plasma 
Table 5. Effects of diet (high or low plane of nutrition) and thiazolidinedione (TZD) treatment (versus saline control) on plasma glucose response to i.v. insulin challenge (IC)

\begin{tabular}{|c|c|c|c|c|c|c|c|c|c|c|c|c|c|c|}
\hline \multirow[b]{2}{*}{ Measure $^{1}$} & \multicolumn{4}{|c|}{ Diet } & \multicolumn{4}{|c|}{ TZD } & \multicolumn{6}{|c|}{ TZD $\times$ diet interaction } \\
\hline & High & Low & SEM & $P$-value & Saline & TZD & SEM & $P$-value & $\begin{array}{c}\text { High } \\
\text { Saline }\end{array}$ & $\begin{array}{l}\text { High } \\
\text { TZD }\end{array}$ & $\begin{array}{l}\text { Low } \\
\text { Saline }\end{array}$ & $\begin{array}{l}\text { Low } \\
\text { TZD }\end{array}$ & SEM & $P$-value \\
\hline Basal glucose $(\mathrm{mg} / \mathrm{dL})$ & 64.5 & 59.1 & 1.5 & 0.02 & 60.9 & 62.7 & 1.5 & 0.43 & 64.6 & 64.3 & 57.2 & 61.1 & 2.2 & 0.33 \\
\hline Minimum glucose $(\mathrm{mg} / \mathrm{dL})$ & 54.7 & 52.0 & 1.1 & 0.12 & 54.0 & 52.7 & 1.2 & 0.43 & 55.8 & 53.6 & 52.3 & 51.7 & 1.7 & 0.64 \\
\hline $\mathrm{CR}(\% / \mathrm{min})$ & 0.46 & 0.24 & 0.12 & 0.22 & 0.34 & 0.37 & 0.12 & 0.86 & 0.44 & 0.49 & 0.24 & 0.25 & 0.35 & 0.91 \\
\hline ISRG ( $\%$ of basal) & 81.2 & 85.1 & 2.1 & 0.21 & 83.8 & 82.6 & 2.1 & 0.68 & 80.4 & 82.0 & 87.1 & 83.1 & 2.9 & 0.34 \\
\hline $\mathrm{AUC}_{15}$ & -34.2 & -22.9 & 12.9 & 0.54 & -12.1 & -45.0 & 12.9 & 0.08 & -19.0 & -49.4 & -5.3 & -40.6 & 18.3 & 0.89 \\
\hline $\mathrm{AUC}_{30}$ & -89.9 & -65.4 & 28.4 & 0.55 & -47.7 & -107.6 & 28.4 & 0.15 & -67.8 & -111.9 & -27.5 & -103.3 & 40.1 & 0.70 \\
\hline $\mathrm{AUC}_{180}$ & 106.8 & 265.8 & 234.4 & 0.64 & 414.4 & -41.8 & 234.4 & 0.18 & 153.3 & 60.4 & 675.5 & -144.0 & 331.4 & 0.28 \\
\hline
\end{tabular}

${ }^{1}$ Basal glucose $=$ mean glucose concentration at -15 and -5 min before IC; minimum glucose $=$ minimum glucose during IC; CR $=$ clearance rate of glucose during IC; ISRG $=$ reduction of plasma glucose from basal levels; $\mathrm{AUC}_{15}=$ area under the curve during the first $15 \mathrm{~min}$ of $\mathrm{IC}$ [ $\mathrm{mg} / \mathrm{dL} \times$ min]; $\mathrm{AUC}$. of $\mathrm{IC}[\mathrm{mg} / \mathrm{dL} \times \mathrm{min}] ; \mathrm{AUC}_{180}=$ area under the curve during the first $180 \mathrm{~min}$ of $\mathrm{IC}[\mathrm{mg} / \mathrm{dL} \times \mathrm{min}]$.

Table 6. Effects of diet (high or low plane of nutrition) and thiazolidinedione (TZD) treatment (versus saline control) on plasma NEFA response to i.v. insulin challenge (IC)

\begin{tabular}{|c|c|c|c|c|c|c|c|c|c|c|c|c|c|c|}
\hline \multirow[b]{2}{*}{ Measure $^{1}$} & \multicolumn{4}{|c|}{ Diet } & \multicolumn{4}{|c|}{ TZD } & \multicolumn{6}{|c|}{ TZD $\times$ diet interaction } \\
\hline & High & Low & SEM & $P$-value & Saline & TZD & SEM & $P$-value & $\begin{array}{c}\text { High } \\
\text { Saline }\end{array}$ & $\begin{array}{l}\text { High } \\
\text { TZD }\end{array}$ & $\begin{array}{l}\text { Low } \\
\text { Saline }\end{array}$ & $\begin{array}{l}\text { Low } \\
\text { TZD }\end{array}$ & SEM & $P$-value \\
\hline Basal NEFA $(\mu \mathrm{Eq} / \mathrm{L})$ & 114.0 & 126.2 & 13.5 & 0.53 & 110.3 & 130.0 & 13.5 & 0.31 & 102.8 & 125.2 & 117.7 & 134.8 & 19.1 & 0.89 \\
\hline Minimum NEFA $(\mu \mathrm{Eq} / \mathrm{L})$ & 97.3 & 114.6 & 10.6 & 0.26 & 104.4 & 107.5 & 10.6 & 0.84 & 87.2 & 107.5 & 121.7 & 107.6 & 14.9 & 0.26 \\
\hline $\mathrm{CR}_{20}(\% / \mathrm{min})$ & 1.8 & 2.6 & 0.45 & 0.21 & 2.0 & 2.4 & 0.45 & 0.56 & 1.0 & 2.4 & 3.0 & 2.2 & 0.63 & 0.08 \\
\hline $\mathrm{T}_{1 / 2}(\mathrm{~min})$ & 76.2 & 71.3 & 36.3 & 0.92 & 88.2 & 59.3 & 34.0 & 0.56 & 80.0 & 72.5 & 96.5 & 46.1 & 47.5 & 0.67 \\
\hline ISRN (\% of basal) & 85.9 & 93.6 & 5.2 & 0.30 & 92.4 & 87.2 & 5.2 & 0.48 & 80.6 & 91.4 & 104.3 & 83.0 & 7.3 & 0.04 \\
\hline $\mathrm{AUC}_{15}$ & 66.2 & 218.6 & 95.5 & 0.28 & 291.1 & -6.4 & 95.1 & 0.04 & 65.2 & 67.3 & 517.1 & -80.0 & 134.5 & 0.04 \\
\hline $\mathrm{AUC}_{30}$ & 87.5 & 375.6 & 241.6 & 0.41 & 563.9 & -100.8 & 239.6 & 0.06 & 149.0 & 26.0 & 978.7 & -227.5 & 338.8 & 0.12 \\
\hline $\mathrm{AUC}_{180}$ & 11,634 & 17,447 & 2,046 & 0.06 & 15,704 & 13,378 & 2,029 & 0.43 & 12,483 & 10,785 & 18,924 & 15,970 & 2,870 & 0.83 \\
\hline
\end{tabular}

을 ${ }^{1}$ Basal NEFA = mean NEFA concentration at -15 and -5 min before IC; minimum NEFA $=$ minimum NEFA during IC; CR20 = clearance rate for NEFA for 20 min post-IC;

$\bullet \quad \mathrm{T}_{1 / 2}=$ half-life for NEFA during IC; ISRN = insulin-stimulated reduction of NEFA during IC; $\mathrm{AUC}_{15}=$ area under the curve during the first 15 min of IC [ $\mu$ Eq/L $\times$ min]; $\mathrm{AUC}$

$=$ area under the curve during the first $30 \mathrm{~min}$ of $\mathrm{IC}[\mu \mathrm{Eq} / \mathrm{L} \times \min ] ; \mathrm{AUC}_{180}=$ area under the curve during the first $180 \mathrm{~min}$ of IC $[\mu \mathrm{Eq} / \mathrm{L} \times \min ]$. 
glucose concentrations over control cows, decreases in plasma glucose concentrations were found with TZD administration (Kushibiki et al., 2001). However, that experiment did not include a control group of cows that were administered TZD and so evaluation of direct effects of TZD on circulating glucose concentrations was not possible. The effects of TZD administration on plasma glucose concentrations might be dependent upon the degree or form of insulin resistance in treated animals. In agreement with previous results, TZD administration did not have an effect on plasma insulin concentrations (Figure 1B). Also consistent with previous results, cows fed the HN diet had increased plasma insulin concentrations throughout the experiment (Holtenius et al., 2003; Dann et al., 2006).

The differences in plasma levels of insulin and NEFA resulted in cows fed the HN diet having a lower overall RQUICKI, which would suggest greater insulin resistance in those cows (Holtenius and Holtenius, 2007). Greater insulin resistance in cows overfed during the dry period has been measured directly in other studies and is suggested as a mechanism by which overfed cows have altered metabolic regulation during the transition period (Holtenius et al., 2003). Similar to the cows evaluated via RQUICKI by Holtenius and Holtenius (2007), the cows in this experiment were clinically healthy and not under metabolic stress. Effective and repeatable evaluation of insulin resistance using RQUICKI in cows with metabolic disorders is lacking (Kerestes et al., 2009). Bossaert et al. (2009) were able to correlate RQUICKI and GTT measures in calves, further illustrating the need for future evaluation of RQUICKI as a measure of insulin sensitivity. Additional weakness in the use of RQUICKI as an appropriate measure in ruminants relates to the changes in plasma concentrations of glucose, insulin, and NEFA that occur during periods of negative energy balance or in metabolic states such as early lactation. In those circumstances, for instance, plasma concentrations of NEFA may be very high whereas insulin especially is very low, thus having a large effect on absolute RQUICKI values. Therefore, using RQUICKI to evaluate cows of different energy status or stage of lactation should be done with caution, and early interpretation should be limited to treatment differences between cows of similar metabolic state. It appears that RQUICKI may be an appropriate measure in some metabolic circumstances but may lack the ability to detect differences in others. In this case, RQUICKI was able to detect dietary treatment differences consistent with previous results; however, agreement with treatment differences measured during GTT and IC were less consistent and unreliable. Further work is necessary to determine the potential use of
RQUICKI to measure differences in insulin resistance in dairy cattle.

Only slight numerical differences were observed in plasma glucose responses to GTT. More interesting, although also not statistically significant, was that cows administered TZD had (numerically) lower insulin secretion in response to GTT (Table 3). This is pointed out because, despite the fact that differences were not observed in the rate of glucose clearance based on TZDtreatment, the TZD-treated cows had to secrete less insulin to clear the glucose, suggesting differences in glucose metabolism. Cows that were receiving chromium-methionine as a means to improve glucose tolerance had reduced secretion of insulin in response to a GTT similar to the one performed here (Hayirli et al., 2001). These results are also interesting when compared with changes in plasma NEFA response to GTT.

The lack of altered response in plasma insulin secretion due to dietary treatment is a reflection of the energy balance met by each of the dietary treatments. Cows in the current experiment fed the LN diet were predicted to be in positive energy balance. As such, negative effects on insulin secretion were not observed. Reduction of insulin responses have been seen in other instances of feed removal and in acidotic cows (Hove, 1978; Bigner et al., 1996). Additional evidence for normal insulin secretion and metabolism in animals fed both the HN and LN diets in the current study are the lack of differences in plasma insulin responses to insulin challenge. Given that no differences were found in insulin responses as measured by AUC, one can assume that insulin clearance did not differ based on dietary or TZD treatment. Differential responses to GTT and IC as measured by changes in plasma glucose and NEFA responses are more likely due then to tissue responses to insulin rather than changes in insulin secretion or clearance.

Additional differences were seen in plasma NEFA responses to GTT (Figure 2, Table 4). Based on differences in clearance rate, AUC, and glucose-stimulated reduction of NEFA, cows fed the LN diet appeared to have more dramatic changes in fatty acid metabolism in response to a glucose infusion. Bines and Morant (1983) hypothesized that thin cows (those fed a lower plane of nutrition) had a more rapid rate of fatty acid synthesis, resulting in lower blood fatty acid precursors and more rapid absorption of volatile fatty acids from the rumen as measured by responses to restricted and ad libitum feeding. The authors also suggested that this may explain why thin cows have a greater ability to increase intake than fat cows. A similar response was quantified by Rukkwamsuk et al. (1999) when they showed that, despite having greater rates of esterifica- 
tion in adipose tissue prepartum, cows overfed during the dry period have higher rates of lipolysis postpartum (Rukkwamsuk et al., 1998).

In one of the few studies to report NEFA responses to GTT, cows were receiving chromium-methionine and NEFA responses to GTT did not differ (Hayirli et al., 2001). Any reported differences by the authors were due to differences in basal levels of NEFA before administration of the GTT. Results were similar for cows administered chromium propionate and then subjected to a similar GTT, where no significant differences in plasma NEFA response to GTT were observed (Sumner et al., 2007). Differences in NEFA responses during IC were observed in this experiment due to TZD administration, which could suggest that, unlike during the use of chromium supplements as an insulin sensitizer, we were seeing additional differences in NEFA responses with TZD administration. Therefore, TZD might be additionally beneficial due to its effects on fatty acid metabolism independent of glucose metabolism. This is consistent with the actions of TZD acting most directly on PPAR $\gamma$ specific to adipose tissue (Sundvold et al., 1997).

Despite having similar responses in plasma insulin concentrations to IC, a tendency was found for cows administered TZD to have more dramatic decreases in plasma glucose concentrations following insulin infusion (Figure 3, Table 5). Previous insulin challenges completed on cows administered TZD did not show significant differences in plasma glucose or insulin responses at 2 insulin challenge doses (Smith et al., 2007). The authors stated this as evidence that TZD does not alter the important adaptation of reduced glucose utilization by skeletal muscle in preparation for lactation. Because TZD is a PPAR $\gamma$ ligand and expression is low in skeletal muscle (Sundvold et al., 1997), this is likely a valid conclusion. Additionally, the cows in the Smith et al. (2007) experiment were administered IC at 9 or $10 \mathrm{~d}$ before expected calving date, a time when insulin resistance of skeletal muscle is likely to be relatively high (Bauman and Currie, 1980). In contrast, the cows in this experiment were $3 \mathrm{wk}$ before calving at the time of the IC, a period when effects on whole-body glucose metabolism might be more measurable. Furthermore, because the concentrations of plasma insulin during IC were similar for cows administered TZD or saline but cows administered TZD experienced more rapid decrease in glucose concentrations during IC, this would suggest that cows administered TZD were more sensitive to the bolus insulin administered during the IC.

Although differences in plasma NEFA responses to GTT were attributed to dietary (vs. TZD) treatment, greater differences in plasma NEFA response to IC were attributed to TZD administration (vs. dietary treat- ment; Table 6). We also found instances of significant interactions of TZD and diet. The result is that cows administered TZD appeared to have a greater response in plasma NEFA concentrations to insulin, a response that may be further amplified in cows fed the LN diet. Furthermore, these differences were observed despite no significant differences in plasma insulin response during IC. This would suggest that differences in plasma NEFA responses to IC are not due to differences in insulin secretion or clearance and are more likely due to adipose tissue response to insulin. Therefore, cows treated with TZD, and especially cows also fed the LN diet, had greater ability of insulin to alter rates of either lipolysis or lipogenesis, or a combination. Treatment of human adipocytes in vitro with thiazolidinediones has been shown to enhance the effects of insulin on lipid metabolism (McTernan et al., 2002). However, the ability of TZD to enhance these effects is lost under situations of chronic hyperinsulinemia (McTernan et al., 2002). This helps to explain how hyperinsulinemic individuals (both obese humans and overfed ruminants) can experience greater rates of lipolysis or BW gain (McTernan et al., 2002; Dann et al., 2006) as responses to insulin may be attenuated during chronic hyperinsulinemic situations. Likewise, responses to insulin-sensitizing interventions (via agents such as TZD or dietary changes) may be dulled in hyperinsulinemic environments as well.

We observed few effects of treatment on mRNA expression within subcutaneous adipose tissue. Although TZD has been shown to increase expression of both LPL and FAS in nonruminants (Kageyama et al., 2003; Bogacka et al., 2004), the effects in ruminants are not yet known. Because both of these genes have been implicated in changes in lipid metabolism occurring during milk fat depression (Harvatine et al., 2009), it was hypothesized that they may play roles in changes in insulin resistance mediated by TZD administration. In this case, however, significant effects were not apparent. In the case of LPL, it may not be a large factor in early lactation but instead may play a greater regulatory role in mid to late lactation (McNamara et al., 1987). A tendency was found for cows fed the HN diet to have increased mRNA expression of LPL, which may be related to increased insulin concentration caused by dietary treatment (Faulconnier et al., 1996).

It is unknown why diet had an effect on PPAR $\gamma$ expression; however, PPAR $\gamma$ expression has been shown in human adipose tissue to be upregulated by insulin and downregulated by a low calorie diet (Vidal-Puig et al., 1997). Although we hypothesized that TZD administration would upregulate PPAR $\gamma$ expression based on previous work in our laboratory (Schoenberg et al., 2011), the reason for the lack of effect in the current study is unknown. Timing relative to calving or dietary 
energy level might have affected the potential for TZD to upregulate PPAR $\gamma$ in ruminants. Additional factors beyond those investigated here regulate changes in fatty acid metabolism due to TZD administration in dairy cattle. Those may include additional adipose tissue-derived signals (i.e., adiponectin, resistin), posttranslational effects on enzymes examined, additional downstream effects, and additional genes not presently analyzed (i.e., other genes involved in fatty acid metabolism, such as hormone-sensitive lipase).

\section{CONCLUSIONS}

The results shown here indicate that changes in insulin resistance may be different in relation to glucose and fatty acid metabolism based on dietary treatment as well as the use of an insulin-sensitizing agent. Although plasma glucose responses to GTT were more pronounced in cows fed a high plane of nutrition, cows fed a lower plane of nutrition had more dramatic responses in plasma NEFA concentrations. These results may be similar to the growing body of evidence that suggests that overfed cows experience changes in energy metabolism that ultimately results in greater loss of body condition and lower DMI postcalving. We expected to see more significant interaction between dietary treatment and TZD administration. The reasons for the lack of interaction may have to do with the experimental design. Rather than complicate measures in energy metabolism by completing the study close to calving, the experiment was conducted in the early dry period in the hopes that responses due to diet and TZD might be more easily characterized. This may have contributed to the overall lack of interactions of TZD and diet. In the future, it might be beneficial to carry a similar experimental design through the transition into early lactation or to subject cows to a period of negative energy balance.

\section{ACKNOWLEDGMENTS}

The authors sincerely appreciate the contribution of the following individuals (all at Cornell University, Ithaca, NY) for completion of this trial: Y. R. Boisclair, R. Ehrhardt, J. Huzzey, L. Winkelman, C. Ryan, J. Ropke, E. Susskind, M. Hurley, B. Pomeroy, R. Watters, R. Higgs, M. Ramos-Nieves, S. Giesy, J. Schoenberg, V. Kim, and the staff at the Cornell University Dairy Teaching and Research Center.

\section{REFERENCES}

Agenäs, S., E. Burstedt, and K. Holtenius. 2003. Effects of feeding intensity during the dry period. 1 . Feed intake, body weight, and milk production. J. Dairy Sci. 86:870-882.
AOAC. 2000. Official Methods of Analysis. 17th ed. Association of Official Analytical Chemists, Arlington, VA.

Bauman, D. E., and W. B. Currie. 1980. Partitioning of nutrients during pregnancy and lactation: A review of mechanisms involving homeostasis and homeorhesis. J. Dairy Sci. 63:1514-1529.

Bigner, D. R., J. P. Goff, M. A. Faust, J. L. Burton, H. D. Tyler, and R. L. Horst. 1996. Acidosis effects on insulin response during glucose tolerance tests in Jersey cows. J. Dairy Sci. 79:2182-2188.

Bines, J. A., and S. V. Morant. 1983. The effect of body condition on metabolic changes associated with intake of food by the cow. Br. J. Nutr. 50:81-89.

Bogacka, I., H. Xie, G. A. Bray, and S. R. Smith. 2004. The effect of pioglitazone on peroxisome proliferator-activated receptor-gamma target genes related to lipid storage in vivo. Diabetes Care $27: 1660-1667$.

Bossaert, P., J. L. Leroy, S. De Campeneere, S. De Vliegher, and G. Opsomer. 2009. Differences in the glucose-induced insulin response and the peripheral insulin responsiveness between neonatal calves of the Belgian Blue, Holstein-Friesian, and East Flemish breeds. J. Dairy Sci. 92:4404-4411.

Coppock, C. E., C. H. Noller, S. A. Wolfe, C. J. Callahan, and J. S. Baker. 1972. Effect of forage-concentrate ratio in complete feeds fed ad libitum on feed intake prepartum and the occurrence of abomasal displacement in dairy cows. J. Dairy Sci. 55:783-789.

Curtis, C. R., N. E. Hollis, J. S. Charles, R. D. Smith, and D. S. Kronfeld. 1985. Path analysis of dry period nutrition, postpartum metabolic and reproductive disorders, and mastitis in Holstein cows. J. Dairy Sci. 68:2347-2360.

Dann, H. M., N. B. Litherland, J. P. Underwood, M. Bionaz, A D'Angelo, J. W. McFadden, and J. K. Drackley. 2006. Diets during far-off and close-up dry periods affect periparturient metabolism and lactation in multiparous cows. J. Dairy Sci. 89:3563-3577.

Dann, H. M., D. E. Morin, G. A. Bollero, M. R. Murphy, and J. K. Drackley. 2005. Prepartum intake, postpartum induction of ketosis, and periparturient disorders affect the metabolic status of dairy cows. J. Dairy Sci. 88:3249-3264.

Dann, H. M., G. A. Varga, and D. E. Putnam. 1999. Improving energy supply to late gestation and early postpartum dairy cows. J. Dairy Sci. 82:1765-1778.

Faulconnier, Y., L. Guillon, and Y. Chilliard. 1996. Lipoprotein lipase and glucose-6-phosphate dehydrogenase activities in bovine and ovine adipose tissue incubated for 7 days: Effects of insulin and/ or dexamethasone. Comp. Biochem. Physiol. B Biochem. Mol. Biol. 113:421-426.

Fronk, T. J., L. H. Schultz, and A. R. Hardie. 1980. Effect of dry period overconditioning on subsequent metabolic disorders and performance of dairy cows. J. Dairy Sci. 63:1080-1090.

Gardner, R. W. 1969. Interactions of energy levels offered to Holstein cows prepartum and postpartum. I. Production responses and blood composition changes. J. Dairy Sci. 52:1973-1984.

Garnsworthy, P. C., and J. H. Topps. 1982. The effect of body condition of dairy cows at calving on their food intake and performance when given complete diets. Anim. Sci. 35:113-119.

Grummer, R. R. 1993. Etiology of lipid-related metabolic disorders in periparturient dairy cows. J. Dairy Sci. 76:3882-3896.

Grummer, R. R. 1995. Impact of changes in organic nutrient metabolism on feeding the transition dairy cow. J. Anim. Sci. 73:28202833.

Hammarstedt, A., C. X. Andersson, V. Rotter Sopasakis, and U. Smith. 2005. The effect of PPARgamma ligands on the adipose tissue in insulin resistance. Prostaglandins Leukot. Essent. Fatty Acids 73:65-75.

Harvatine, K. J., and D. E. Bauman. 2006. SREBP1 and thyroid hormone responsive spot 14 (S14) are involved in the regulation of bovine mammary lipid synthesis during diet-induced milk fat depression and treatment with CLA. J. Nutr. 136:2468-2474.

Harvatine, K. J., J. W. Perfield, and D. E. Bauman. 2009. Expression of enzymes and key regulators of lipid synthesis is upregulated in adipose tissue during CLA-induced milk fat depression in dairy cows. J. Nutr. 139:849-854. 
Hayirli, A., D. R. Bremmer, S. J. Bertics, M. T. Socha, and R. R. Grummer. 2001. Effect of chromium supplementation on production and metabolic parameters in periparturient dairy cows. J. Dairy Sci. 84:1218-1230.

Holtenius, K., S. Agenas, C. Delavaud, and Y. Chilliard. 2003. Effects of feeding intensity during the dry period. 2. Metabolic and hormonal responses. J. Dairy Sci. 86:883-891.

Holtenius, P., and K. Holtenius. 2007. A model to estimate insulin sensitivity in dairy cows. Acta Vet. Scand. 49:29-31.

Holtenius, P., G. Olsson, M. Emanuelson, and H. Wiktorsson. 1996. Effects of different energy levels, concentrate/forage ratios and lipid supplementation to the diet on the adaptation of the energy metabolism at calving in dairy cows. Zentralbl. Veterinarmed. A 43:427-435.

Houseknecht, K. L., and D. E. Bauman. 1997. Regulation of lipolysis by somatotropin: Functional alteration of adrenergic and adenosine signaling in bovine adipose tissue. J. Endocrinol. 152:465-475.

Hove, K. 1978. Insulin secretion in lactating cows: Responses to glucose infused intravenously in normal, ketonemic, and starved animals. J. Dairy Sci. 61:1407-1413.

Kageyama, H., T. Hirano, K. Okada, T. Ebara, A. Kageyama, T. Murakami, S. Shioda, and M. Adachi. 2003. Lipoprotein lipase mRNA in white adipose tissue but not in skeletal muscle is increased by pioglitazone through PPAR-gamma. Biochem. Biophys. Res. Commun. 305:22-27.

Kerestes, M., V. Faigl, M. Kulcsar, O. Balogh, J. Foldi, H. Febel, Y. Chilliard, and G. Huszenicza. 2009. Periparturient insulin secretion and whole-body insulin responsiveness in dairy cows showing various forms of ketone pattern with or without puerperal metritis. Domest. Anim. Endocrinol. 37:250-261.

Komatsu, T., F. Itoh, S. Kushibiki, and K. Hodate. 2005. Changes in gene expression of glucose transporters in lactating and nonlactating cows. J. Anim. Sci. 83:557-564.

Kushibiki, S., K. Hodate, H. Shingu, Y. Ueda, M. Shinoda, Y. Mori, T. Itoh, and Y. Yokomizo. 2001. Insulin resistance induced in dairy steers by tumor necrosis factor alpha is partially reversed by 2,4-thiazolidinedione. Domest. Anim. Endocrinol. 21:25-37.

Licitra, G., T. M. Hernandez, and P. J. Van Soest. 1996. Standardization of procedures for nitrogen fractionation of ruminant feeds. Anim. Feed Sci. Technol. 57:347-358.

McNamara, J. P., D. C. McFarland, and S. Bai. 1987. Regulation of bovine adipose tissue metabolism during lactation. 3. Adaptations of hormone-sensitive and lipoprotein lipases. J. Dairy Sci. 70:1377-1384.

McTernan, P. G., A. L. Harte, L. A. Anderson, A. Green, S. A. Smith, J. C. Holder, A. H. Barnett, M. C. Eggo, and S. Kumar. 2002. Insulin and rosiglitazone regulation of lipolysis and lipogenesis in human adipose tissue in vitro. Diabetes 51:1493-1498.

Morrow, D. A. 1976. Fat cow syndrome. J. Dairy Sci. 59:1625-1629.

Murondoti, A., R. Jorritsma, A. C. Beynen, T. Wensing, and M. J. H. Geelen. 2004. Unrestricted feed intake during the dry period impairs the postpartum oxidation and synthesis of fatty acids in the liver of dairy cows. J. Dairy Sci. 87:672-679.

Nikkhah, A., J. J. Loor, R. L. Wallace, D. Graugnard, J. Vasquez, B. Richards, and J. K. Drackley. 2008. Moderate excesses of dietary energy markedly increase visceral adipose tissue mass in non-lactating dairy cows. J. Dairy Sci. 86(E-Suppl. 1):ii. (Abstr.)
NRC. 2001. Nutrient Requirements of Dairy Cattle. 7th rev. ed. National Academy Press, Washington, DC.

Pires, J. A., A. H. Souza, and R. R. Grummer. 2007. Induction of hyperlipidemia by intravenous infusion of tallow emulsion causes insulin resistance in Holstein cows. J. Dairy Sci. 90:2735-2744.

Richards, B. F., N. A. Janovick, K. M. B. D. E. Moyes, and J. K. Drackley. 2010. Comparison of a controlled-energy high-fiber diet fed throughout the dry period to a two-stage far-off and close-up dietary strategy. J. Dairy Sci. 87(E-Suppl. 1):88. (Abstr.)

Rukkwamsuk, T., T. Wensing, and M. J. Geelen. 1998. Effect of overfeeding during the dry period on regulation of adipose tissue metabolism in dairy cows during the periparturient period. J. Dairy Sci. 81:2904-2911.

Rukkwamsuk, T., T. Wensing, and M. J. Geelen. 1999. Effect of overfeeding during the dry period on the rate of esterification in adipose tissue of dairy cows during the periparturient period. J. Dairy Sci. 82:1164-1169.

Schoenberg, K. M., K. L. Perfield, J. K. Farney, B. J. Bradford, Y. R. Boisclair, and T. R. Overton. 2011. Effects of prepartum 2,4-thiazolidinedione on insulin sensitivity, plasma concentrations of tumor necrosis factor alpha and leptin, and adipose tissue gene expression. J. Dairy Sci. 94:5523-5532.

Sirois, P. K., M. J. Reuter, C. M. Laughlin, and P. J. Lockwood. 1994. A method for determining macro and micro elements in forages and feeds by inductively coupled plasma atomic emission spectrometry. Spectroscopist 3:6-9.

Smith, K. L., W. R. Butler, and T. R. Overton. 2009. Effects of prepartum 2,4-thiazolidinedione on metabolism and performance in transition dairy cows. J. Dairy Sci. 92:3623-3633.

Smith, K. L., S. E. Stebulis, M. R. Waldron, and T. R. Overton. 2007. Prepartum 2,4-thiazolidinedione alters metabolic dynamics and dry matter intake of dairy cows. J. Dairy Sci. 90:3660-3670.

Sumner, J. M., F. Valdez, and J. P. McNamara. 2007. Effects of chromium propionate on response to an intravenous glucose tolerance test in growing Holstein heifers. J. Dairy Sci. 90:3467-3474.

Sundvold, H., A. Brzozowska, and S. Lien. 1997. Characterisation of bovine peroxisome proliferator-activated receptors gamma 1 and gamma 2: Genetic mapping and differential expression of the two isoforms. Biochem. Biophys. Res. Commun. 239:857-861.

Van Soest, P. J., J. B. Robertson, and B. A. Lewis. 1991. Methods for dietary fiber, neutral detergent fiber, and nonstarch polysaccharides in relation to animal nutrition. J. Dairy Sci. 74:3583-3597.

Vazquez-Añon, M., S. Bertics, M. Luck, R. R. Grummer, and J. Pinheiro. 1994. Peripartum liver triglyceride and plasma metabolites in dairy cows. J. Dairy Sci. 77:1521-1528.

Vernon, R. G. 2005. Lipid metabolism during lactation: A review of adipose tissue-liver interactions and the development of fatty liver. J. Dairy Res. 72:460-469.

Vidal-Puig, A. J., R. V. Considine, M. Jimenez-Linan, A. Werman, W. J. Pories, J. F. Caro, and J. S. Flier. 1997. TI - Peroxisome proliferator-activated receptor gene expression in human tissues. Effects of obesity, weight loss, and regulation by insulin and glucocorticoids. J. Clin. Invest. 99:2416-2422.

Wildman, E. E., G. M. Jones, P. E. Wagner, R. L. Boman, J. Troutt, and T. N. Lesch. 1982. A dairy cow body condition scoring system and its relationship to selected production characteristics. J. Dairy Sci. 65:495-501. 